(RESEARCH ARTICLE)

\title{
Improvement of the chemical properties of waste rock deposits at the Agbaou gold mine by the legume Pueraria phasoeloïdes (Center-west Côte d'Ivoire)
}

\author{
Sylla Daouda 1, ${ }^{*}$, Pascal Kouassi Thehua Angui 1, Amand Christelle and Epouse Vanga 2 \\ ${ }^{1}$ Laboratory of Geosciences and Environment UFR Sciences and Environmental Management, NANGUI ABROGOUA \\ University, 02 BP 801 Abidjan 02, Côte d'Ivoire. \\ 2 Department of Health, Safety and Environment (HSE) of the Agbaou gold mine.
}

Publication history: Received on 27 September 2020; revised on 23 October 2020; accepted on 27 October 2020

Article DOI: https://doi.org/10.30574/wjarr.2020.8.1.0360

\begin{abstract}
Objective: To assess the effects of the legume (Pueraria phasoeloïdes) on the chemical parameters of the waste rock soils (saprolites) at the Agbaou gold mine, in the center-west of Côte d'Ivoire.

Methodology and results: Soil samples were taken using the systematic sampling method at regular intervals of $20 \mathrm{~m}$ on the ramps and at $20 \mathrm{~cm}$ soil depth, using an auger during two consecutive sampling campaigns (2016-2017 and 2017-2018). The geometric coordinates of the sampling points were obtained using a GPS Garming CSX60 type. A total of 20 composite samples were made from 80 collected soil samples. Chemical analyzes were carried out on soil samples obtained. The results show that the contents of total organic carbon (TOC), total organic nitrogen (Nt), the C: $\mathrm{N}$ ratio and the $\mathrm{pH}$ values of the soils, under Pueraria phaseoloïdes legume were significantly improved between the ramps and between the two campaigns ( $\mathrm{p}<0.05)$. Conversely, (CEC, exchangeable bases, $\left(\mathrm{Ca}^{2+}, \mathrm{Mg}^{2+}\right.$ and $\left.\mathrm{K}^{+}\right)$and phosphorus contents decreased significantly $(p<0.001)$ between the ramps and the two campaigns. This reflects the improving effect of the legume on the chemical parameters of the soils. However, variations in trace element content between ramps and across campaigns did not show any significant improvement $(\mathrm{p}>0.05)$.
\end{abstract}

Keywords: Mining site; legume; degraded soils; rehabilitation; waste rock park; saprolite; chemical properties of the soil; Agbaou gold mine

\section{Introduction}

The policy of Côte d'Ivoire has been reoriented towards the exploitation of subsoil resources in recent decades to increase state revenue. This new vision does not go without causing damage to the environment, where soil is an important component. Mining has a negative impact on components such as water, soil, air and flora (Christine, 2002; GREP, 2012). It leads to the destruction of vegetation cover, deforestation, environmental pollution, loss of biodiversity (Taylor et al., 2004; Jaques et al., 2006; Ouédraogo, 2006; Andriamasinoro et al.). Water erosion is accelerated with an aggravation of soil degradation (Maradan et al., 2011).

Several authors (Didby, 1999; Johane, 2011) have proposed solutions to mitigate the adverse effects of mining activities on the environnement. These includes soil restoration, site rehabilitation, phytoremediation, mycoremediation, preplanting grassing and levelling of barren rock piles followed by topsoil cover. Surfaces are then seeded with grasses such as Pennisetum pedicellatum and Andropogon gayanus (Hardarson and Danso, 1993).

\footnotetext{
* Corresponding author: Sylla Daouda

Laboratoire Géosciences et Environnement UFR Sciences et Gestion de l’Environnement, Université NANGUI ABROGOUA, 02 BP 801 Abidjan 02, Côte d'Ivoire.
} 
Fallowing with Pueraria phaseoloïdes improves the organic status of the soil (organic carbon and total nitrogen contents) through a faster decomposition of legume litter. Pueraria phaseoloides litter contains less lignin and has a low C:N ratio (Tian et al., 1997). According to the authors, impoved fallow with this legume maintains the organic carbon status better than natural fallow. Several works have shown that organic fertilization and fallow, using legumes, reinforced soil quality (Dupuy and N'Guessan, 1990; Olivier and Ganry, 1994; Gnahoua, 1997; Autfray and Gbakatchetche, 1998; Harmand and Balle, 2001; Melendez et al, 2003). Compost, green manure, associated with poultry manures (Ganry et al., 2000; Akanza and Yoro, 2003) also improved soil quality. Hien (2004) and Bado (2002) have shown that organic matter and nitrogen contents influenced soil quality. Legumes were also found to improve nitrogen balance in cropping systems (Bado, 2002).

In Côte d'Ivoire, despite the increasing extension of mining sites across the country, with its corollary of soil degradation, generated waste land has not benefited from real rehabilitation programs using plant species. The present study, entitled "Improvement of the chemical properties of the soils of the tailings ponds of the Agbaou gold mine by the leguminous Pueraria Phasoeloïdes", aims to propose a solution for the rehabilitation of wasteland parks resulting from mining activities at Agbaou in a perspective of a sustainable management of agricultural soils.

\section{Material and methods}

\subsection{Description of the Study Site}

The study was conducted at the Agbaou gold mine in northwestern Côte d'Ivoire, located at approximately $200 \mathrm{~km}$ from Abidjan (Figure 1).

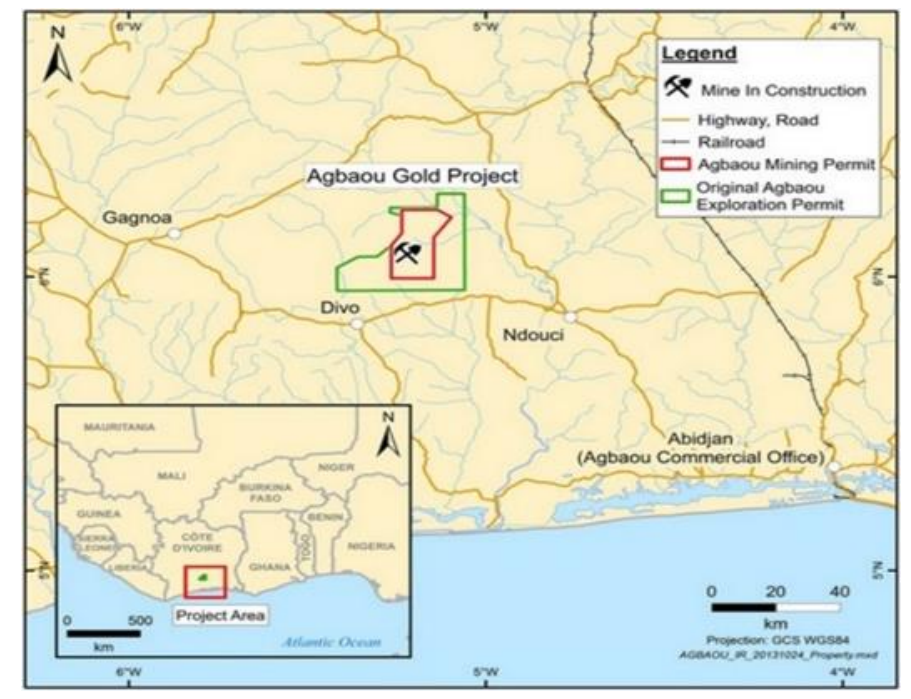

Figure 1 Location of the Agbaou Gold Mine

The study area is contained within the Agbaou exploration permit, in northwestern Côte d'Ivoire in the southern part of Bandama and the Divo District. The climate is humid subtropical and transitional equatorial (Tié, 2005). The driest months are January and December, while the wettest month is June, with rainfall of up to $210 \mathrm{~mm}$. The highest annual rainfall is $1,235.4 \mathrm{~mm}$ and the lowest $103 \mathrm{~mm}$ (SODEXAM, 2000). Maximum temperatures are between $31^{\circ}$ and $38^{\circ} \mathrm{C}$ and minimums between $10^{\circ}$ and $21^{\circ} \mathrm{C}$.

\subsection{Plant material}

Pueraria phaseoloïdes is a herbaceous, coiled legume, with branches up to $15 \mathrm{~m}$ long. The stems are cylindrical, equipment with and trifoliate leaves. The number of seeds varies from 8 to 25 per pod, about 3 mm long and dark brown in color (Acevedo-Rodríguez, 2005). It is deeply rooted (up to $2 \mathrm{~m}$ depth), with hairy stems that can reach a length between 6 and $15 \mathrm{~m}$ and a diameter of $0.6 \mathrm{~cm}$ (FAO, 2015; Cook et al., 2005; Halim, 1997). It is a plant species whose systematic position is as follows: Kingdom: plant, Branch: spermatophyte (seed plants), Division: magnoliophyta (flowering plants), Class: magnoliopsida (dicotyledons), Order: Fabales, Family Fabaceae, Genus: Pueraria (kudzu), Species: Pueraria Phaseoloïdes. 


\subsection{Geological material}

Rock formations of the Agbaou gold deposit corresponding to the "Sillon de Roches Vertes" Oumé-Fétêkro, of Birrimian age. The rocks encountered are essentially deformed mafic volcanites metamorphosed in the green schist facies. A folded greenstone belt, with deposits located, not far from the anticlinal hinge of the fold on the eastern flank can also be observed. The deposit is located in the northeast-trending shear zone separating meta-volcanites to the east and meta-sediments to the west. Rocks consist of volcanic meta, meta-sediments, tuffs and mylonites (Golder, 2008).

\subsection{Soil characteristics}

\subsubsection{Topsoil}

Soils are classified in this area contain coarse materials such as ferruginous gravel, laterite and quartz fragments. Chemical analysis revealed that all soils have a high cation exchange capacity and that the saturation of these complexes is adequate (Tié, 2005).

\subsubsection{Saprolite}

It is a thick layer of soil with $10 \mathrm{~m}$ of laterite formed above the deposit. A transition zone developed at the lower oxidation limit over the healthy rock. It originates from weathered metavolcanites rokcs. On a regional scale, the saprolite has a typical thickness of 70 to $100 \mathrm{~m}$, which can vary over the deposit from $10 \mathrm{~m}$ (west) to $120 \mathrm{~m}$ (northeast). Saprolite thickness varies from 10 to $20 \mathrm{~m}$, and is generally found at a depth of $70 \mathrm{~m}$ in the Agbaou deposit.

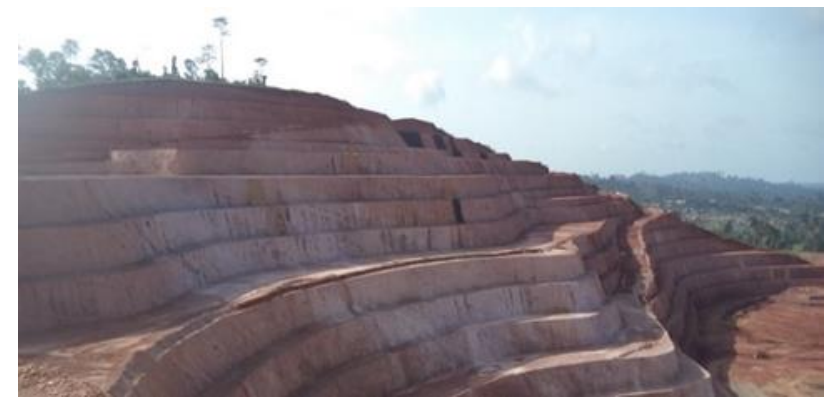

Figure 2 A quarry showing staged ore extraction (saprolite ramps)

\subsection{Construction of the sterile park}

The waste rock extracted from the open-pit quarries, was transported and stored in a dumping site or waste rock park. The waste rock stockpile is constructed so that the waste rock extracted from the surface of the quarry is placed at the base of the slope and the material extracted further down the quarry is deposited on the top of the ramp hill, in the form of an inverted relief. When a ramp level is constructed, it is covered with a thin layer of "topsoil". Then seeds of Pueraria phaseoloïdes are sown and teak plants (Tectonia grandis) are planted at $10 \mathrm{~m}$ intervals to stabilize the slopes of the hill thus constructed.

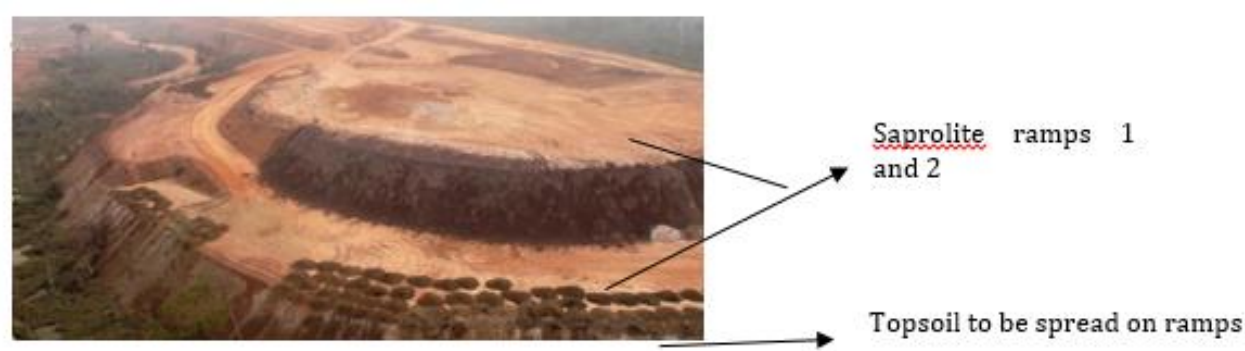

Figure 3 Hill under construction, with sterile saprolite showing the stairway (ramps) layouts 


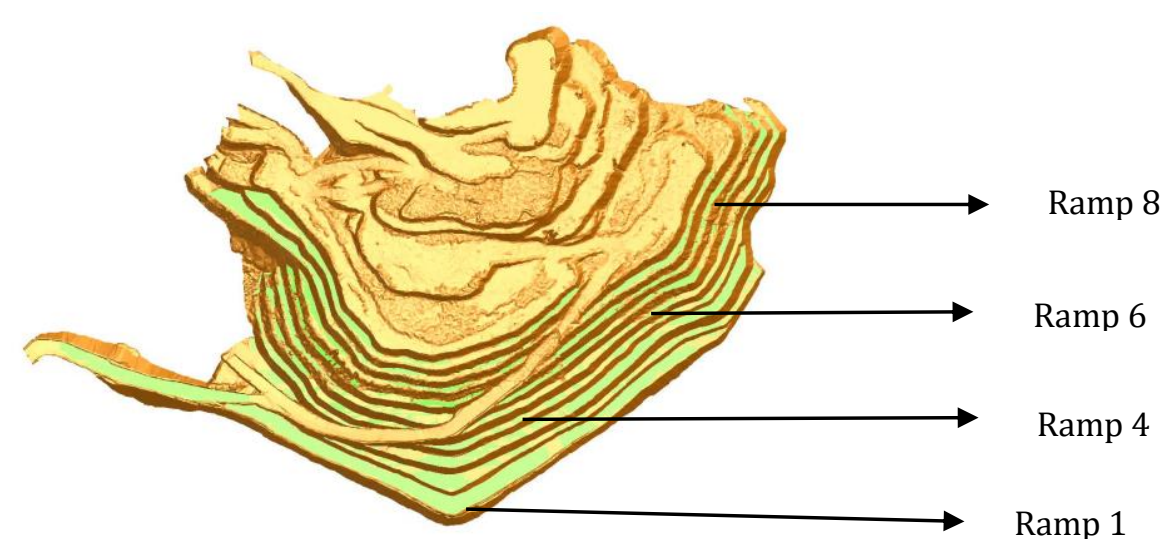

Figure 4 Randomly sampled ramps layont where soil samples were collected.

NB: Ramps 1, 4, 6 and 8: Ramps where soil samples were collected

Ramps 2 and 3 were not sampled because used as path for saprolite transportation to waste dump site

\subsection{Sampling method}

Soil samples were collected using the systematic sampling method. Samples were taken at regular intervals (20 m) along the ramps, at depths of 0-20 cm in two consecutives sampling campaigns (2016-2017 and 2017-2018). The geometric coordinates of the sampling points were obtained using a GPS, Garming CSX60 type. A total of 20 composite samples were constituted from 80 soil samples collected. Chemical analyses were carried out on the soil samples. The sample plots are covered with Pueraria phalosoïdes.

\subsection{Chemical analysis}

\subsubsection{Determination of Total Organic Carbon}

The total organic carbon content of the soil was determined using the Walkley-Black methods (Anderson and Ingram,1993). A potassium dichromate $\left(\mathrm{K}_{2} \mathrm{Cr}_{2} \mathrm{O}_{7}\right), 1 \mathrm{~N}$ solution was added to a given mass of dry soil in the presence of sulphuric acid $\left(\mathrm{H}_{2} \mathrm{SO}_{4}\right)$ and concentrated phosphoric acid $\left(\mathrm{H}_{3} \mathrm{PO}_{4}\right)$. The solution obtained was titrated with a $0.5 \mathrm{~N}$ solution of ferrous sulphate $\left(\mathrm{FeSO}_{4}\right)$ in the presence of ferroin as an indicator.

\subsubsection{Determination of Total Nitrogen}

Total nitrogen was determined using the Kjeldahl method (Anderson and Ingram, 1993). A given quantity of soil was mineralized by a sulfuric acid attack in cylinders in a heating block under a fume hooded. After mineralization, the contents of the cylinders were titrated to determine the $N$ content of the soil.

\subsubsection{Determination of Cationic Exchange Capacity}

The determination of cation exchange capacity (CEC) was carried out using the ammonium acetate $\left(\mathrm{NH}_{4} \mathrm{OAc}\right)$ method (1M, pH 7) (Anderson and Ingram, 1993).

\subsubsection{Determination of Phosphorus}

The determination of total phosphorus was carried out using the method by Duval (1962). A solution containing 32P043- ions was injected into a mixture of given soil: solution ratio. After filtration under pressure, the remaining radioactivity was determined.

\subsubsection{Determination of Trace Elements}

The determination of trace elements was carried out using the Duchallfour and Bonneau method.

A quantity of ground soil was added to sulfuric acid $\left(\mathrm{H}_{2} \mathrm{SO}_{4}\right)$ to precipitate humic acids. Then soda was added to the mixture. After centrifugation, standards solutions were prepared (Duval (1962). 


\subsection{Statistical analysis of the data}

The data obtained were subjected to an analysis of variance (ANOVA), with a post-hoc test (Mann-Whitney and Wilcoxon) for the comparison of means. Where significant differences were observed, at the $5 \%$ probability level, these tests were performed using R-Studio software.

\section{Results and discussion}

The results show a variation in chemical parameters from one ramp to another and from one campaign to another. The figure below shows a sterile park planted with Pueraria phaseoloïdes and Tectonia grandis.

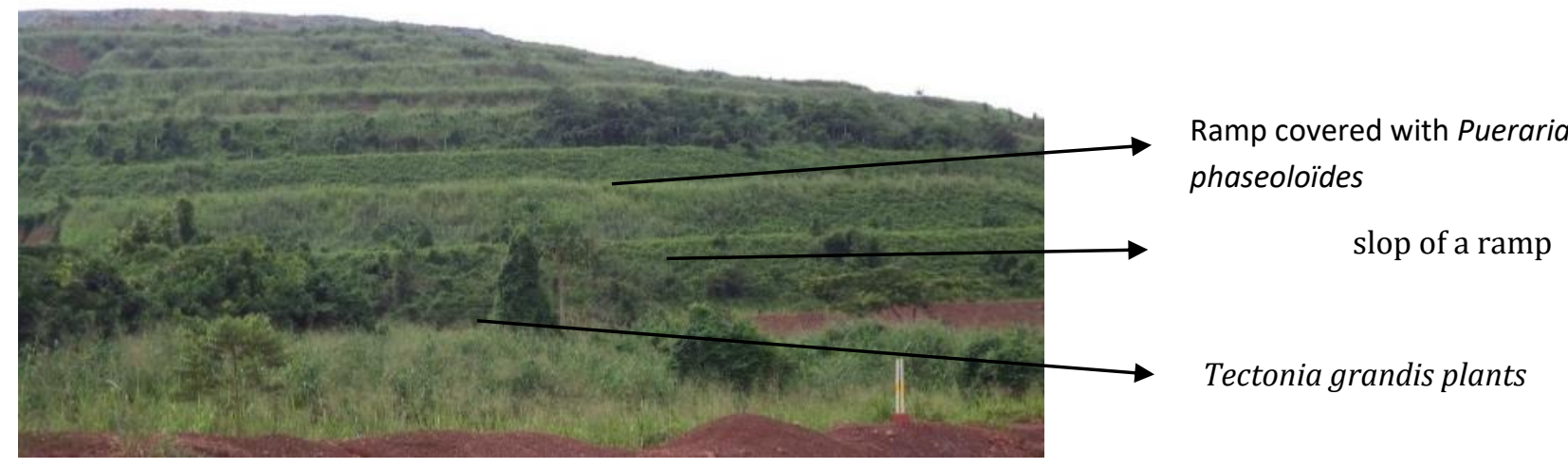

Figure 5 View of a sterile park planted with Pueraria phaseoloïdes and Tectonia grandis and naturally colonized by Panicum maximum, Trema orientalis, etc. species.

\subsection{Soil Acidity}

Figure 6 shows the $\mathrm{pH}$ values of the soil in the sterile saprolite. At the end of the first season, there was a significant drop in $\mathrm{pH}$ from ramp 1 (5.03) to ramp 8 (4.65). At the end of the second campaign, there is a slight decrease in $\mathrm{pH}$ values from ramp 1 (5.05) to ramp 8 (4.9). From the first season to the second, two years of legume colonization, there is a significant increase in $\mathrm{pH}$, especially at ramps 4, 6 and 8. Values ranged from 4.83 to 4.9 for Ramp 4, 4.75 to 4.9 for Ramp 6 and 4.65 to 4.9 for Ramp 8. The highest $\mathrm{pH}$ values were obtained on ramp 1 (bottom of the slope) and the lowest on ramp 8 located at the top of the hill. The large variations in $\mathrm{pH}$ between ramps were obtained between ramps 1 and 6 and between ramps 1 and 8, due to the effect of the legume cover over time. However, non-significant pH variations were obtained between ramps 1 and 4, ramps 4 and 6 and between ramps 6 and 8 . In general, due to the effect of Pueraria phaseoloïdes, the pH values of the waste rock increased from one season to another and decreased from the lower slopes to the upper slopes.

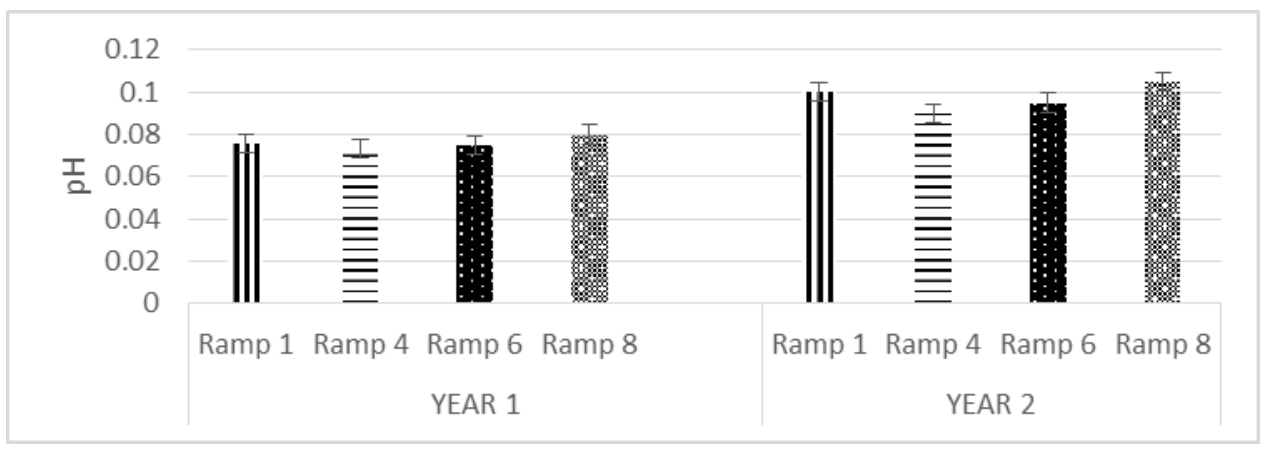

Figure 6 Evolution of soil pH under Pueraria phaseoloïdes as a function of ramps and campaigns. 


\subsection{Total organic carbon content, total organic nitrogen content and $\mathrm{C}: \mathrm{N}$ ratio}

\subsubsection{Total Organic Nitrogen}

In the first campaign, the differences observed between the total organic carbon (TOC) contents were not significant (Figure 7). In the second campaign, the differences were not significant either. However, from the first campaign to the second, there was a significant increase in the levels (Ramp 1: 0.81 to 1.15\%; Ramp 4: 0.77 to 1.02\%; Ramp 6: 0.78 to 1.08\% and Ramp 8: 0.83 to $1.19 \%$ ), due to the effect of Pueraria phaseoloides. Overall, TOC levels increased significantly in both campaigns, but not between ramps.

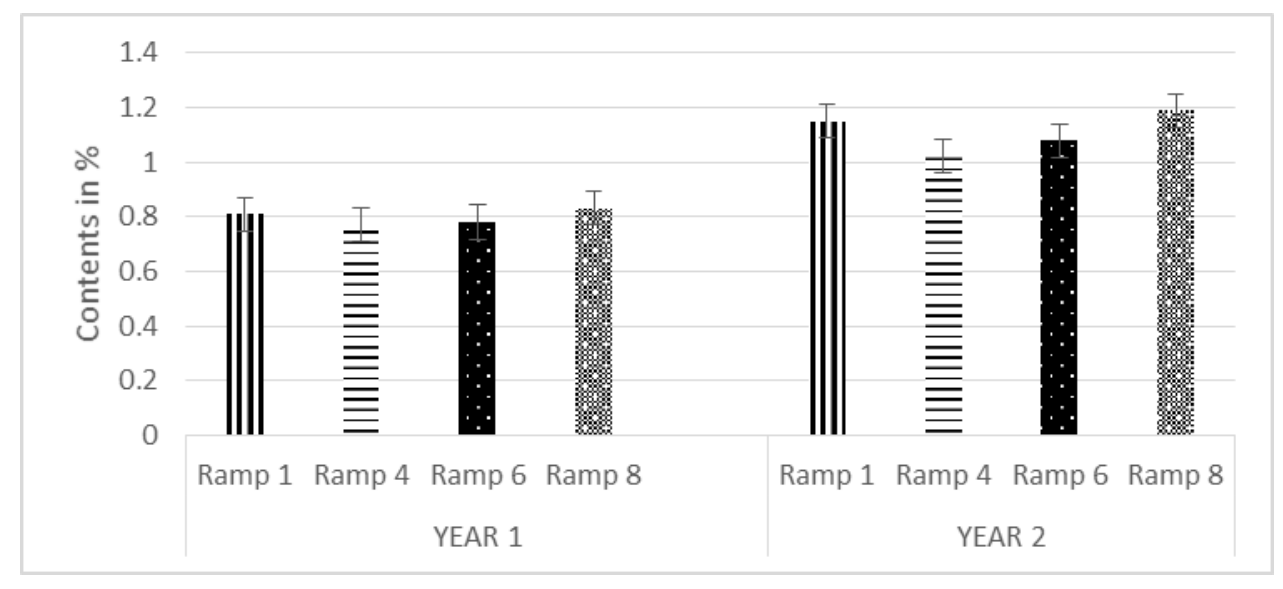

Figure 7 Evolution of total organic carbon content of soils under Pueraria phaseoloïdes as a function of ramps and campaigns.

\subsubsection{Total nitrogen content}

Total soil organic $\mathrm{N}$ levels are shown in Figure 8. At the end of the first year, the differences observed between soil contents under the effect of Pueraria phaseoloïdes were not significant. These values ranged from $0.81 \%$ for Ramp 1 to $0.83 \%$ for Ramp 8. At the end of the second year, the differences observed between the soil contents under the effect of Pueraria phaseoloïdes were not as significant (ramp 1=1.15\% and ramp $8=1.19 \%$ ). But from the first to the second year, the differences observed between these contents were very highly significant. These contents are between 0.81 and $1.15 \%$ for Ramp 1, between 0.77 and $1.02 \%$ for Ramp 4, between 0.78 and $1.08 \%$ for Ramp 6 and finally between 0.83 and $1.19 \%$ for Ramp 8.

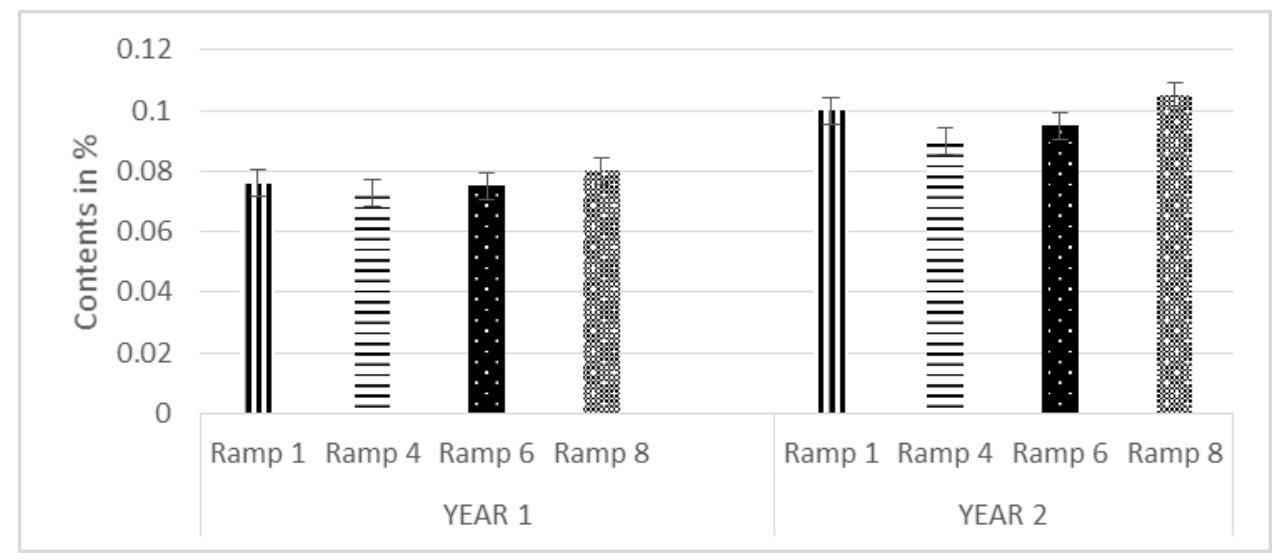

Figure 8 Evaluation of the average total nitrogen content of soils under Pueraria according to ramps and years

\subsubsection{Soil C:N ratios}

Not surprisingly, soil C:N ratios followed the same trends as soil $\mathrm{N}$ and $\mathrm{C}$ levels, both within and across ramps. For example, there were significant increases of 10.65 to $11.5 \%$ within Ramp $1 ; 10.54$ to $11.33 \%$ within Ramp 4 ; 10.4 to $11.36 \%$ within Ramp 6; and 10.37 to $11.33 \%$ by the end of the second year (Figure 9). In general, organic compound 
contents did not increase between ramps but underwent very significant increases during the years, due to Pueraria phaseoloïdes.

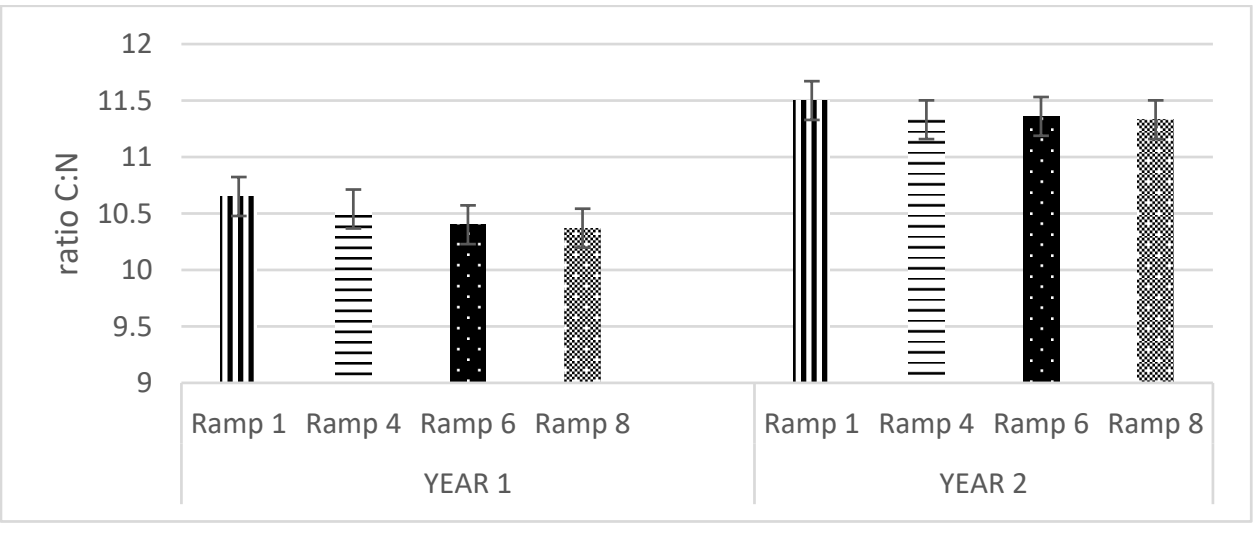

Figure 9 Evaluation of the average ratios C: $\mathrm{N}$ of soils under Pueraria, as a function of ramps and years

\subsection{Cation exchange capacity (CEC)}

Figure 10 shows the variations in inter-years and intra-ramp CEC. There was a significant decrease in CEC from Ramp 1 (7.93 cmol.kg- $\left.{ }^{-1}\right)$ to Ramp 8 (5.7 cmol.kg- $\left.{ }^{-1}\right)$ during the first year. In the second year, there was a significant decrease in CEC from Ramp 1 (8.29 cmol.kg- ${ }^{-1}$ ) to Ramp 8 (6.2 cmol.kg- $\left.{ }^{-1}\right)$. However, no significant difference was observed between the CEC levels of the ramp soils during the two years.

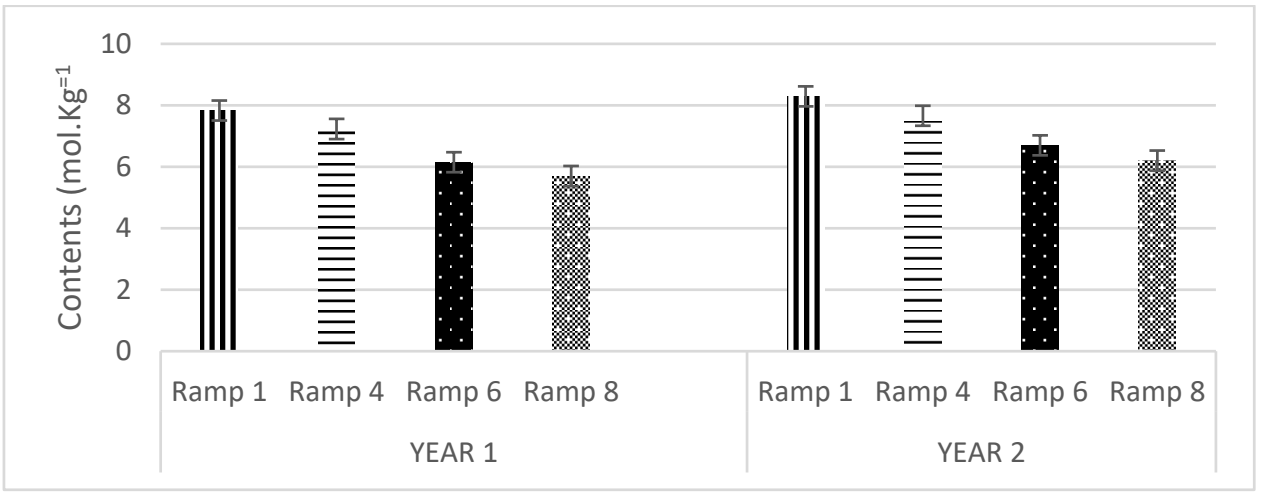

Figure 10 Evolution of CEC of the soils under Pueraria as a function of ramps and years

\subsection{Exchangeable bases}

\subsubsection{Calcium content}

At the end of the first year, there is a decrease in Ca2+ levels from boom $1(0.85 \mathrm{cmol} . \mathrm{kg}-1)$ to boom $8(0.59 \mathrm{cmol} . \mathrm{kg}-1)$. At the end of the second year, levels also decreased significantly from boom $1(0.96 \mathrm{cmol} . \mathrm{kg}-1)$ to boom $8(0.6 \mathrm{cmol} . \mathrm{kg}$ 1). However, no significant difference was observed between the Ca2+ levels in the soils of the booms in the two years. (Figure 11). 


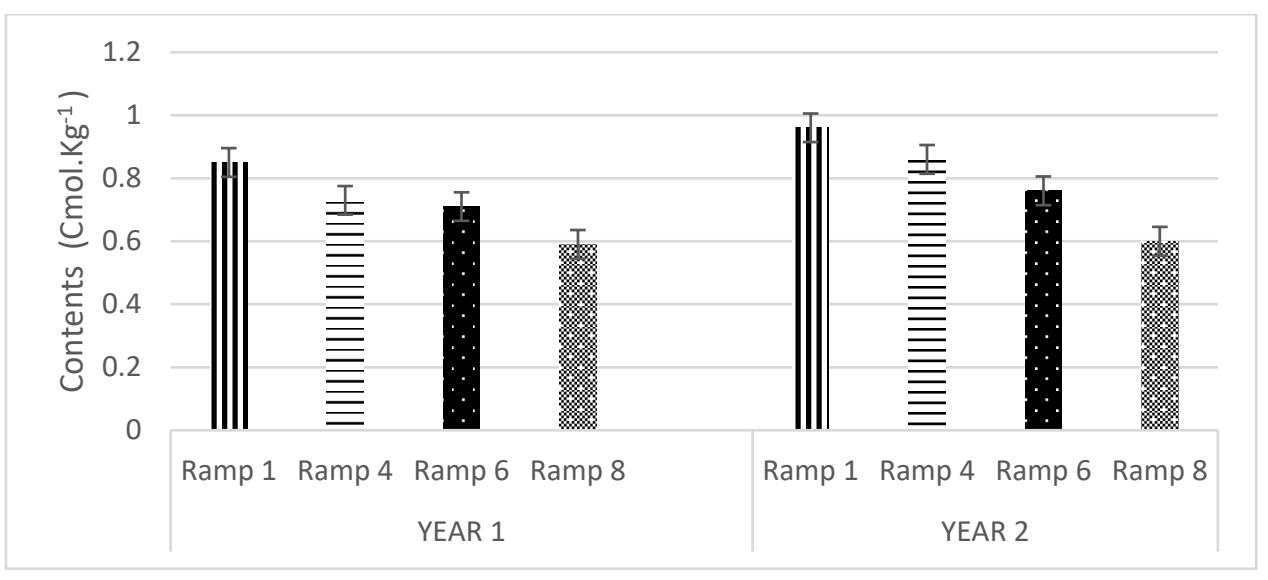

Figure 11 Evolution of Ca2+ contents in soils under Pueraria as a function of ramps and years

\subsubsection{Magnesium content}

With the exception of the $\mathrm{Mg}^{2+}$ soil contents in Ramp 6, the comparison of soil contents also decreased at the end of the first year, from Ramp $1(0.44 \mathrm{cmol.kg}-1)$ to Ramp $8(0.073 \mathrm{cmol} . \mathrm{kg}-1)$. At the end of the second year, levels also decreased from boom $1(0.45 \mathrm{cmol.kg}-1)$ to boom $8(0.43 \mathrm{cmol.kg}-1)$. However, no significant difference was also observed between the soil contents of the booms in the two years (Figure 12).

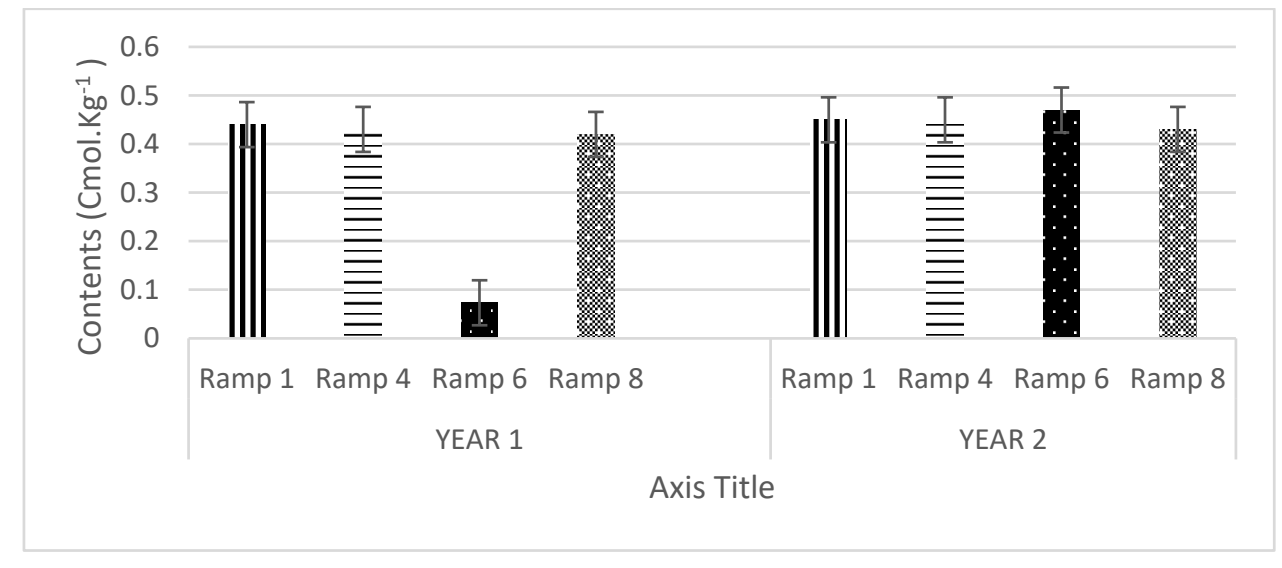

Figure 12 Evolution of $\mathrm{Mg}^{2+}$ soil contents under Pueraria as a function of ramps and years.

\subsubsection{Potassium content}

In contrast to the levels of other exchangeable soil cations, the $\mathrm{K}^{+}$cations did not differ significantly between the ramps at the end of the first and second year. However, there were very significant differences in these levels between the two years. Thus, levels increased at Ramp 1 (from $0.085 \mathrm{cmol.kg}-1$ to $0.1 \mathrm{cmol.kg}-1$ ), Ramp 4 (from $0.085 \mathrm{cmol} . \mathrm{kg}-1$ to 0.1 cmol.kg-1), Ramp 6 (from 0.073 cmol.kg-1 to 0.09 cmol.kg-1), and Ramp 8 (from 0.078 cmol.kg-1 to 0.1), over two seasons (Figure 13).

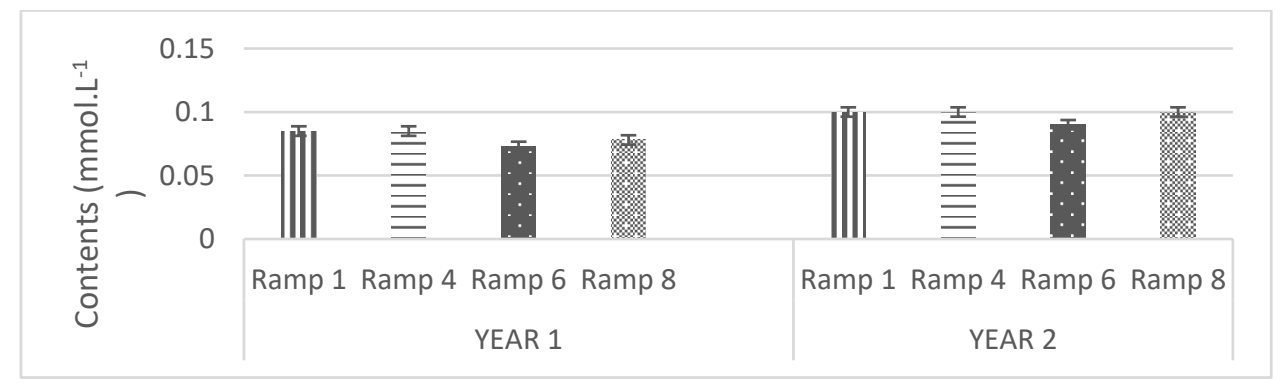

Figure 13 Evolution of soil $\mathrm{K}+$ contents under Pueraria as a function of ramps and years 


\subsection{Total phosphorus content}

From year 1 to year 2, variations in Ptot levels showed significant differences between the ramps. However, no significant differences were found in soil contents between the ramps at the end of year 1 and year 2 . Thus, we obtained increases in Ptot levels in Ramp 1 (from 365.66 to 377.33 ppm), Ramp 4 (366.66 to 379.33 ppm), Ramp 6 (from 287.5 to $298 \mathrm{ppm}$ ) and Ramp 8 (from 323.5 to 334.5 ppm) (Figure 14).

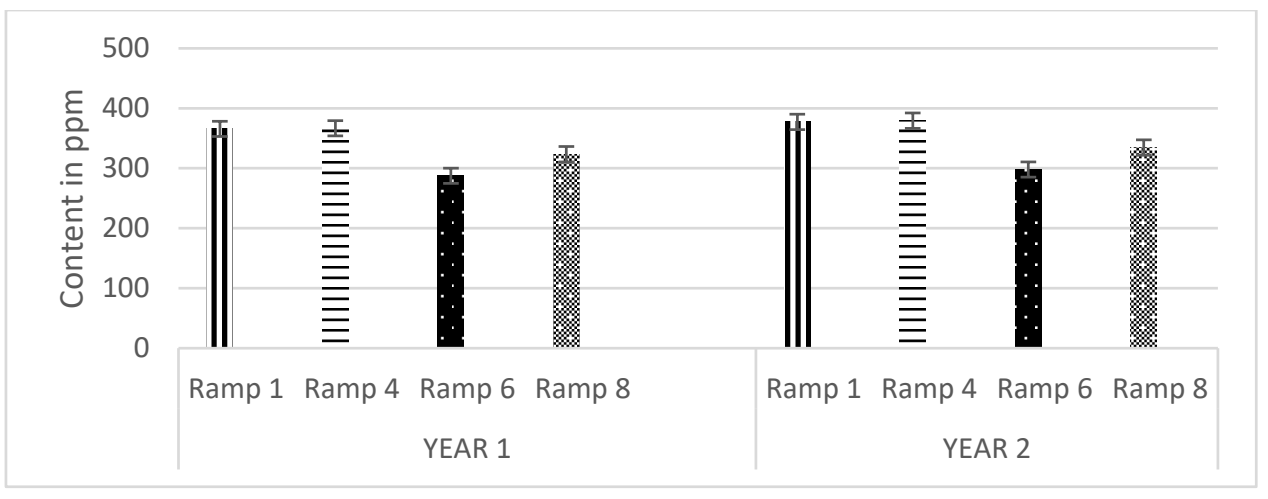

Figure 14 Evolution of Ptot contents in soils under Pueraria as a function of ramps and years

\subsection{Trace element contents}

The main trace elements that were analyzed during this study are: $\mathrm{Zn}, \mathrm{Bo}, \mathrm{Cu}, \mathrm{Co}$, and Mo. This choice is explained by the fact that these elements are the most decisive in the effects of Pueraria phaseoloïdes on soil trace elements.

\subsection{1. zinc content}

Figure 15 shows that in the first year, Zn levels decreased from Ramp 1 (1.311 ppm) to Ramp 8 (0.888 ppm). In the second year, levels also decreased from ramp $1(1.314 \mathrm{ppm})$ to ramp $8(0.895 \mathrm{ppm})$. From year 1 to year 2 , either. two years of colonization by Pueraria phaseoloïdes, there was a non-significant increase in levels, especially at all ramps: ramp 1 (from 1.311 to $1.314 \mathrm{ppm}$ ), ramp 4 (from 1.157 to $1.165 \mathrm{ppm}$ ), ramp 6 (from 1.037 to $1.048 \mathrm{ppm}$ ) and ramp 8 (from 0.888 to $0.895 \mathrm{ppm}$ ).

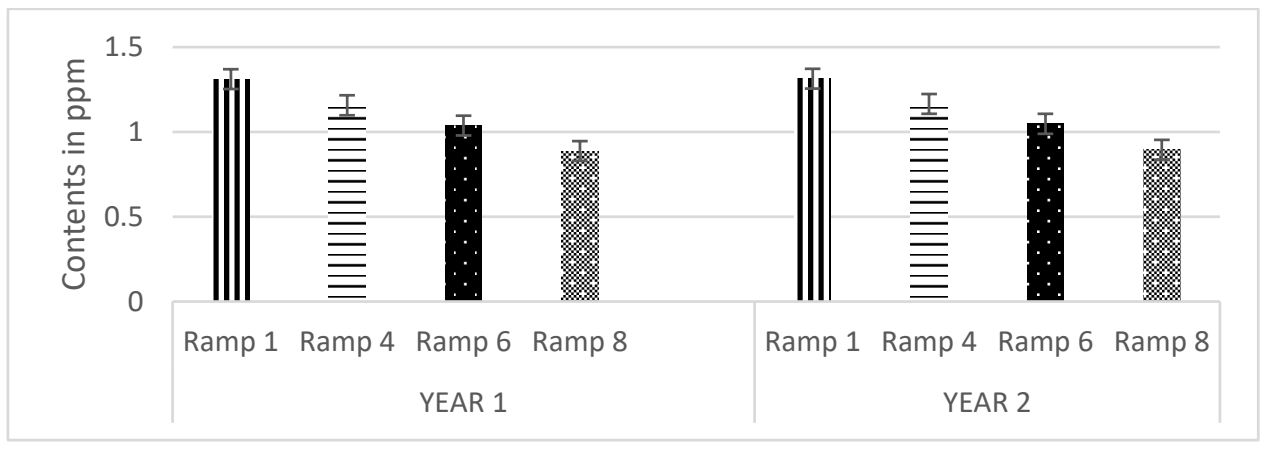

Figure 15 Evolution of Zn contents in soils under Pueraria as a function of ramps and years

\subsubsection{Boron contents}

Figure 16 shows that in the first year, soil B levels decreased from Ramp $1(0.288 \mathrm{ppm})$ to Ramp 8 (0.2505 ppm). In the second year, soil levels also decreased from Ramp $1(0.301 \mathrm{ppm})$ to Ramp 8 (0.273 ppm). From year 1 to year 2 , two years of colonization by Pueraria phaseoloides, there was also a non-significant increase in soil levels, especially at all the ramps: ramp 1 (from 0.288 ppm to $0.301 \mathrm{ppm}$ ), ramp 4 (from 0.257 ppm to $0.267 \mathrm{ppm}$ ), ramp 6 (from $0.261 \mathrm{ppm}$ to $0.281 \mathrm{ppm}$ ) and ramp 8 (from $0.2505 \mathrm{ppm}$ to $0.273 \mathrm{ppm}$ ). Figure 16. 


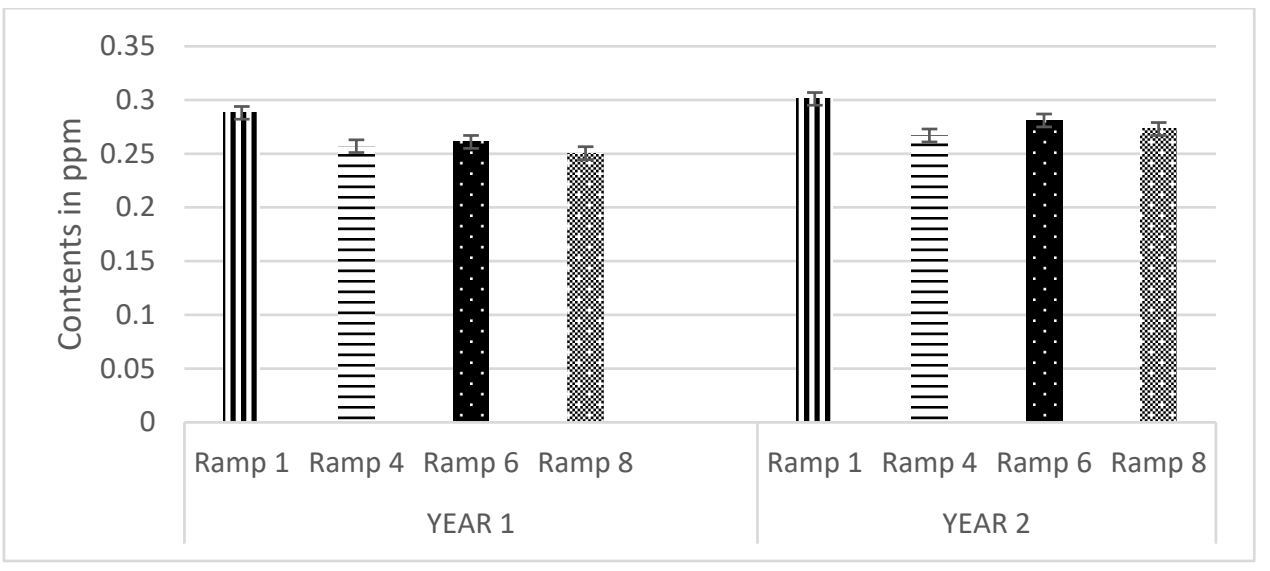

Figure 16 Evolution of B contents in soils under Pueraria as a function of ramps and years

\subsubsection{Copper contents}

In the first year, soil Cu levels decreased from Ramp $1(0.21 \mathrm{ppm})$ to Ramp $8(0.163 \mathrm{ppm})$. In the second year, soil levels also decreased from Ramp $1(0.22 \mathrm{ppm})$ to Ramp $8(0.169 \mathrm{ppm})$. From year 1 to year 2, either two years of colonisation by Pueraria phaseoloïdes, there was also a non-significant increase in levels, especially at all the ramps: ramp 1 (from $0.21 \mathrm{ppm}$ to $0.22 \mathrm{ppm}$ ), ramp 4 (from $0.177 \mathrm{ppm}$ to $0.18 \mathrm{ppm}$ ), ramp 6 (from $0.161 \mathrm{ppm}$ to $0.166 \mathrm{ppm}$ ) and ramp 8 (from $0.163 \mathrm{ppm}$ to $0.169 \mathrm{ppm}$ ) Figure 17.

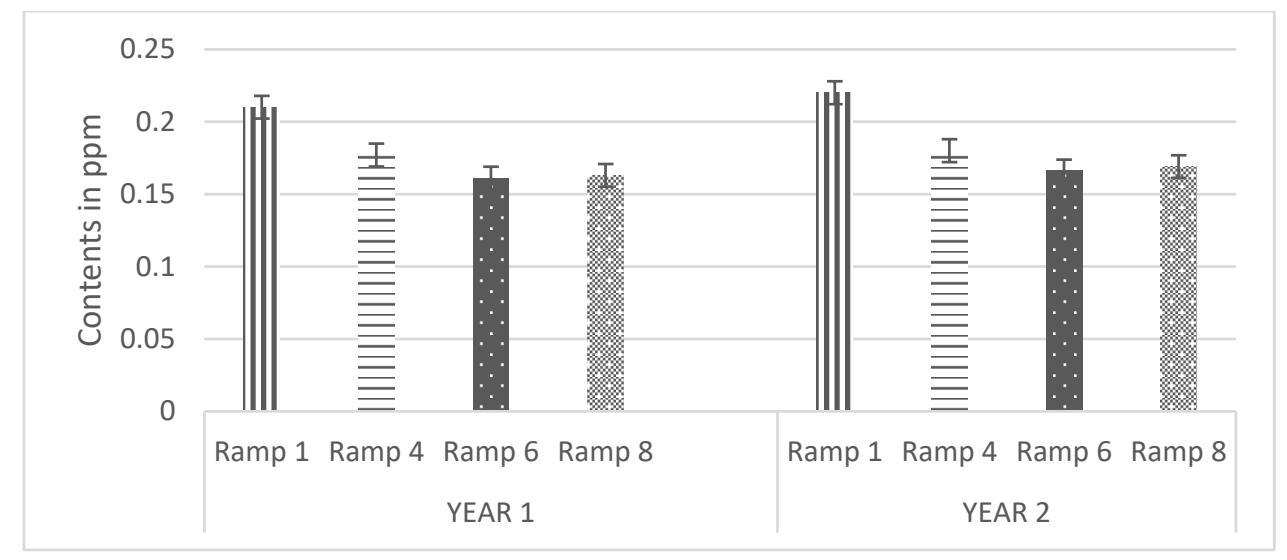

Figure 17 Evolution of $\mathrm{Cu}$ contents in soils under Pueraria as a function of ramps and years

\subsubsection{Cobalt contents}

At the end of the first year in 2016, with the exception of soil levels in Ramp 8, the other levels increased insignificantly from Ramp $1(0.064 \mathrm{ppm})$ to Ramp $6(0.116 \mathrm{ppm})$. At the end of the second year, levels also increased from ramp 1 $(0.069 \mathrm{ppm})$ to ramp $6(0.13 \mathrm{ppm})$, except for soil levels in ramp 8, which had the lowest levels. From year 1 to year 2 , there was also a non-significant increase in soil levels, especially at all ramps. Ramp 1: $0.064 \mathrm{ppm}$ to $0.069 \mathrm{ppm}$ ); Ramp 4: $0.098 \mathrm{ppm}$ to $0.102 \mathrm{ppm}$, Ramp 6: $0.116 \mathrm{ppm}$ to $0.13 \mathrm{ppm}$ and Ramp 8 (0.014 ppm to 0.0255) Figure18. 


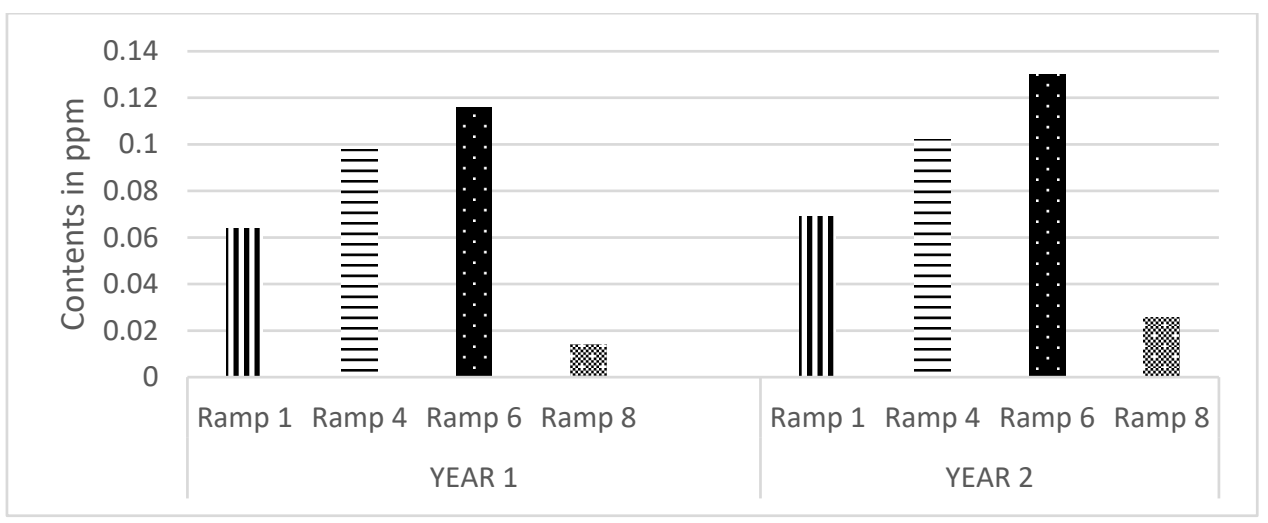

Figure 18 Evolution of Co contents in soils under Pueraria as a function of ramps and years

\subsubsection{Molybdenum contents}

At the end of the first year, soil Mo levels decreased significantly from Ramp $1(0.012 \mathrm{ppm})$ to Ramp 8 (0.016 ppm). At the end of the second year, soil Mo levels increased from ramp $1(0.0166 \mathrm{ppm})$ to ramp $4(0.013 \mathrm{ppm})$. These levels then increased at Ramp 6 (0.019 ppm) and finally decreased at Ramp $8(0.016 \mathrm{ppm})$. Over the two years, there were significant increases in soil levels at the ramps: Ramp 1 (from $0.012 \mathrm{ppm}$ to $0.0166 \mathrm{ppm}$ ), Ramp 4 (from $0.01 \mathrm{ppm}$ to $0.013 \mathrm{ppm}$ ), Ramp 6 (from $0.0125 \mathrm{ppm}$ to $0.019 \mathrm{ppm}$ ) and Ramp 8 (0.009 ppm to $0.016 \mathrm{ppm}$ ) Fig. 19. Overall, soil Mo levels increased significantly while soil $\mathrm{Co}, \mathrm{Zn}, \mathrm{B}$ and $\mathrm{Cu}$ levels did not increase significantly during the campaigns, due to the effect of Pueraria phaseoloïdes.

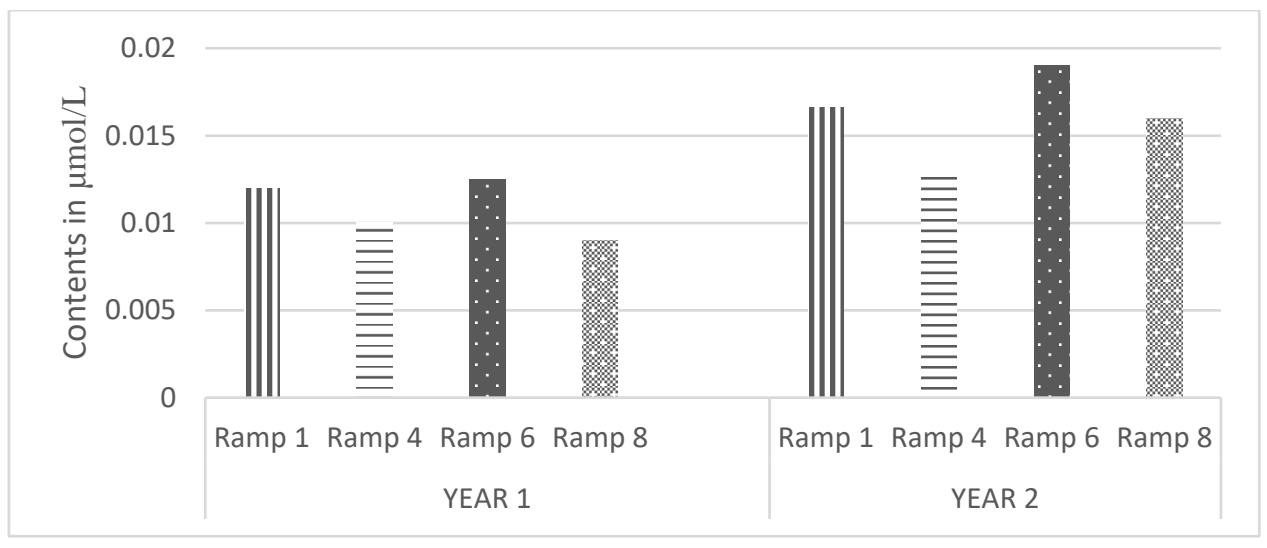

Figure 19 Evolution of Mo contents in soils under Pueraria as a function of ramps and years

\section{Discussion}

The significant effects ( $\mathrm{p}<0.05)$ of the legume Pueraria phaseoloïdes on soil chemical parameters were demonstrated by the improvement of $\mathrm{pH}, \mathrm{CEC}$, total organic carbon, total organic nitrogen, $\mathrm{C}: \mathrm{N}$ ratio, exchangeable bases, total phosphorus and trace elements over the sampling years. Pueraria phaseoloïdes fallow has been shown to improve soil chemical properties (Tian et al., 1997). These fallows, through their decomposition in the soil, ensure high nutrient availability after cultivation. Their use in the fertilization of the soils of the barren park of the Agbaou gold mine has been beneficial for these soils. The increase in $\mathrm{pH}$ from season 1 to season 2 is related to the increase in exchangeable bases in the soil solution and organic matter produced by Pueraria phaseoloïdes. Many studies have shown a considerable increase in the concentrations of the main base cations $(\mathrm{Ca}, \mathrm{Mg}, \mathrm{K})$ in the soil after repeated input of organic matter (from plant biomass, micro and macro organisms) (Parkinson et al., 1999; Mbonigaba, 2007; Mze, 2008). However, increases in $\mathrm{pH}$ values between ramps are mainly related to the nature of the starting soils. Indeed, the fact that the waste rock from the quarry is stored in the park in an inverted manner (the superficial layers of the quarry are found at the bottom of the slope and the deep layers at the top of the slope) greatly affects the variations in levels between ramps. The exchange acidity comes from the hydrogen and aluminum ions in the exchange complex. pH is often used as an indicator of aluminum activity. Organic matter input improves soil $\mathrm{pH}$ both in acidic soil by its buffering capacity and the input of bases ( $\mathrm{Ca}, \mathrm{Mg}, \mathrm{K}, \mathrm{Na}$ ) and in basic soil by increasing the cation exchange capacity (CEC) at the level of the clay-humic complexes. These complexes increase the buffering capacity of the soil and its capacity to resist 
$\mathrm{pH}$ variations. The decrease in acidity between the two campaigns is due to the decomposition of Pueraria phaseoloïdes leaves. This decomposition ensures a better availability of nutrients in the soil. Organic matter combines with the ions responsible for acidity (Al, Fe, $\mathrm{Mn}$ ) to form stable complexes (Djébré, 2008). The contents of exchangeable bases $\left(\mathrm{Ca}^{2+}\right.$ and $\mathrm{Mg}^{2+}$ ), which have been improved by Pueraria phaseoloides during the two years, would be sufficient to neutralize the ions responsible for soil acidity. Indeed, the $\mathrm{Ca}^{2+}$ ion, antagonistic to $\mathrm{Al}^{3+}$, displaces it from the clay-humic complex. The greater the quantities of $\mathrm{Ca}^{2+}$ and $\mathrm{Mg}^{2+}$, the greater the neutralization of $\mathrm{H}^{+}$and $\mathrm{Al}^{3+}$ ions and, consequently, the acidity was reduced. This corroborates the results of Djébré, 2008, which indicated that $\mathrm{Al}^{3+}$ contents had significantly decreased with increasing doses of lime and dolomite inductors. According to Brady and Weil, 2002, the contribution of organic matter can improve soil acidity by the following three ways: (i) fixation of aluminum by humic matter, thereby limiting its toxicity; (ii) formation of soluble aluminum complexes with low molecular weight organic acids produced by microbial decomposition and root exudation; and (iii) addition of mineral elements can cause $\mathrm{pH}$ to increase and lead to the formation of poorly soluble, non-exchangeable Al compounds. Indeed, in soils, the variation in CEC is a function of the content of organic matter and clays, which are generally dependent in quantity and quality on the natural weathering conditions of the parent rock (Gobat et al., 1998). Organic matter plays an important role in the availability of CEC when the availability of soil mineral fractions is low, for example in sandy soils and many tropical soils with variable loadings where CEC decreases with pH (Bertrand and Gigou, 2000). Under these conditions the soil retains more mineral salts, which promotes root nutrition and inhibits ion leaching.

For organic nitrogen and organic carbon, the increases in total organic carbon, total organic nitrogen and C:N ratio would be due to leaf drop in the latter before harvest. These leaves are sources of potentially mineralizable organic matter, and thus a source of nutrients including carbon and nitrogen. Indeed, Pueraria Phasoeloïdes litter contains less lignin and has a very low C:N ratio (Tian et al., 2000). According to these authors, Pueraria Phasoeloïdes fallow maintained the organic carbon status better than natural fallow. In Carimagua, Colombia, using the ${ }^{13} \mathrm{C}$ abundance technique, Rao et al. (1994), cited by Tian et al. (2001), detected only 29 p.c. of soil organic carbon under a one-year-old Pueraria Phasoeloïdes fallow. Our results are in agreement with those of several authors, including Danso (1995) cited by Bado (2002). According to these authors, nitrogen fixed in the atmosphere contributes 50 to 60 p.c. of the nitrogen in seed legumes. Legume residues are richer in nitrogen and contribute to enriching the soil with nitrogen and carbon elements. In a corn/legume cover crop combination, Odunze and al. (2002) showed that total soil nitrogen was improved compared to the initial soil nitrogen content after two years of cultivation.

Soil rehabilitation of the barren tailings slopes of the Agbaou gold mine by Pueraria phaseoloïdes did not result in a significant improvement ( $p>0.05$ ) in exchangeable base and CEC during the two sampling campaigns. This could be explained by the fact that the Pueraria Phasoeloïdes took up significant amounts of these elements from the soil solution on the one hand and these elements could not be released from the source rocks into solution on the other hand. Indeed, Pueraria phasoeloïdes is a leguminous plant that uses nutrients such as $\mathrm{Ca}^{2+}, \mathrm{Mg}^{2+}, \mathrm{P}$ and $\mathrm{K}^{+}$for better symbiotic nitrogen fixation and also for its growth (Bado, 2002). Thus, without the addition of external mineral elements, this legume will draw these elements and the exchangeable bases from the soil solution, resulting in a decrease in these elements during the growing season. Watson (1960) found that the $\mathrm{Ca}^{2+}$ content of the leaf, stem and nodules was increased by setting at $\mathrm{pH}$ 6.0, with a smaller increase with setting at $\mathrm{pH}$ 7.0. It is a legume that is a consumer of high quality calcium and is usually highly calcareous. Loustalot and Telford (1948) found that lack of $\mathrm{Ca}^{2+}$ caused root system rot. The chlorophyll in the leaves faded along the margins and between the main veins, and the green was replaced by a buff pigment around the midrib.

Pueraria phaseoloïdes did not cause a significant increase in phosphorus levels during two sampling campaigns. This is due to the fact that it removed P from the soil solution for its growth. These results are consistent with the work of Obatolu and Agboola (1993) who noted the enrichment of exchangeable bases and phosphorus in soils under Chromolaena odorata compared to Pueraria phaseoloïdes fallow. Dirven and Ehrencron (1969) found that omission of phosphorus resulted in less developed plants. Our results are in agreement with the work of Grof (1966) who, after growing plants on P-free soils, found them to be chlorotic and weak. Dirven and Ehrencron (1969) found that P deficiency resulted in stunted growth. Only a few new leaves and vines were formed and the leaves were small and rigid, olive-green in colour and, in some cases, the leaf margin was wavy in the middle. The work of Loustalot and Telford (1948) also confirms our results. These authors found that $\mathrm{K}^{+}$deficiency produced partial chlorosis and/or necrosis between the veins. The basal leaves were affected first, later the apex. In the absence of $\mathrm{K}^{+}$, yields were 87 percent of the maximum yield of complete fertilizer, and nodules were abnormally large and moderately numerous. Landrau et al (1953) found that they competed unsuccessfully with merker grass (Pennisetum purpureum) for small supplies of $\mathrm{K}^{+}$in the soil.

Contrary to other exchangeable bases, the potassium contents were not significantly different between the soils of the different ramps, but significant differences could be obtained between the two campaigns, due to the effect of Pueraria 
Phasoeloïdes. These highly significant differences would be attributable to the rock weathering phenomenon and leaching. Indeed, during rock alteration, the white mica contained in the rocks degrades to potassium. Due to the leaching process and the nature of the source soils (healthy rocks are at the top and altered rocks at the bottom of the slope), the white mica, during its alteration to potassium, is carried to the lower ramps (Ramp 1), resulting in high concentrations in these ramps. The concentration gradient of potassium levels in the ramps follows the following descending order: $85 \%$ ramp 1; 85\% ramp 4; 81\% ramp 6 and 78\% ramp 8 . It is as if the $\mathrm{K}^{+}$levels in the soils in the booms decrease as you move up the upper ramps.

With the exception of molybdenum, the effects produced by Pueraria phaseoloïdes on the soil contents of the trace elements studied did not cause any significant improvement ( $p>0.05)$, either between ramps or between campaigns. This could be explained by the fact that these soils are poor in these microelements, on the one hand, and the living Pueraria phaseoloïdes biomass releases fewer micronutrients in the decomposition process of the dead biomass, on the other hand. Indeed, the microelements are released into the soil preferentially depending on the state (dry, living or dead) of the Pueraria phaseolö̈des plant. To determine the accumulation of Pueraria phaseolö̈des micronutrients, according to age, established as soil cover in industrial oil palm crops, an experiment was carried out at Companhia, in the municipality of Tailândia, State of Pará, in an Oxisol. Two types of ground cover were established, one comprising dry matter from living Pueraria phaseoloïdes plants, and the other dead ground cover. Thus, the reduction in micronutrient content in live Pueraria phaseoloides was less than in the dead plant cover. This can be explained by the reduction in physiological activity in the production of biomass in addition to the decrease in light intensity resulting from palm growth. For dead plant cover, a decrease in micronutrient content may be associated with an increase in the decay process of plant tissue, causing carbon volatilization and nutrient release through microbial activity (Brady; Weil, 2013; Sequeira, 2007). The results concluded that the accumulation of nutrients, except for magnesium and copper in the living plant cover of Pueraria phaseoloïdes decreased over time and that the accumulation of boron, magnesium, zinc and copper was greater in the dead plant of Pueraria phaseoloïdes and for $\mathrm{Cl}$ was greater in the living plant cover of Pueraria phaseoloides. The descending order of total micronutrient extraction was as follows: $\mathrm{Cl}>\mathrm{Mn}>\mathrm{B}>\mathrm{Zn}>\mathrm{Cu}$. These results are in agreement with ours because during the two sampling campaigns, the living plant cover of Pueraria phaseoloïdes could not significantly ( $\mathrm{p}>0.05)$ increase the micro-nutrient contents of the study area, with the exception of molybdenum. In contrast to the other microelements, the living plant cover of Pueraria phaseoloids significantly $(\mathrm{p}<0.05)$ increased the molybdenum contents between the ramps and between the two campaigns in the study area. This could be explained by the fact that Pueraria phaseoloïdes release molybdenum into the soil during its growth. Indeed, Watson (1960) found that the calcium content of Pueraria phaseoloïdes leaves, stems and nodules increased when heated to pH 6 and also increased less when heated to pH 7. Liming releases molybdenum, especially at pH 7 with a significant increase in $\mathrm{Ca}$ and Mo.

\section{Conclusion}

The study revealed that Pueraria phasoeloides improve soil organic status by increasing total organic carbon, total nitrogen and C:N ratio after only two years at the Agbaou gold mine. It also showed beneficial effects on soil pH. pH values were improved during the two sampling campaigns. It can be stated that the improved fallow of Pueraria phasoeloïdes allows an increase in $\mathrm{pH}, \mathrm{C.O.T}$, Nt and C:N. On the other hand, the improved fallow of Pueraria phasoeloïdes did not allow an improvement in the contents of exchangeable bases, phosphorus and trace elements, with the exception of Mo, especially as the contents obtained at the end of the campaigns were low. The values obtained on the soils of the first season show, compared to those of the second season, losses of contents in proportion to time. Indeed, the contents of phosphorus and exchangeable bases, with the exception of potassium, decreased significantly, while the contents of trace elements remained constant, with the exception of molybdenum. This leads us to certify that certain chemical parameters of the soils are further improved with Pueraria phasoeloïdes fallow, while others suffer losses and some remain constant. Thus, Pueraria phasoeloïdes offer great potential in the rehabilitation of sterile slopes. In the long term, the medium can be reused as agricultural land. Their integration in the management of the fertility of these soils in the Central-West Ivorian region could be recommended. The economic profitability of this legume, linked to its high requirement of topsoil for its growth, is a limiting factor in its use. It would be interesting to evaluate, in the future, other legumes less demanding in topsoil such as Centrosema pubescens and Mimosa pudica on the yields of sterile worms, their influence on the chemical parameters of mining soils. 


\section{Compliance with ethical standards}

\section{Acknowledgments}

This manuscript was produced thanks to the institutional, financial and logistical support of the Endeavour Company, Centre Ivoirien Antipollution (CIAPOL). Our sincere thanks go to Mr BEHA Zehegolo Arsène (Regional Director of CIAPOL in Yamoussoukro), OUATTARA Ekra Kassoum (Health, Safety and Environment Director of Endeavour's HSE Department), AMAND Christelle Epse VANGA (Environmental Coordinator of Endeavour's HSE Department) and the entire team of the HSE Department of the Agbaou Gold Mine for their invaluable and multifaceted assistance in the realization of this work.

\section{Disclosure of conflict of interest}

The authors declare that there is no conflict of interest between them or any other party regarding this article.

\section{References}

[1] Loustalot AJ, Telford EA. Physiological Experiments with Tropical Kudzu 1. Agronomy Journal. 1948 Jun 1; 40(6):503-11.

[2] Landrau Jr P, Samuels G. Results of Lime and Minor-Element Fertilizer Research in Puerto Rico, 1949-50. The Journal of Agriculture of the University of Puerto Rico. 1956; 40(4):224-34.

[3] Landrau Jr P, Samuels G, Rodriguez P. Influence of fertilizers, minor elements, and soil ph on the growth and protein content of tropical kudzu. The Journal of Agriculture of the University of Puerto Rico. 1953; 37(1):81-95.

[4] Bado B.V., Role of legumes on the fertility of tropical ferruginous soils in the Guinean and Sudanian zones of Burkina Faso. Doctoral thesis, Université de Laval, Quebec, 146 p. 2002.

[5] Watson GA. Interactions of lime and molybdate in the nutrition of Centrosema pubescens and Pueraria phaseoloides. Journal of the Rubber Research Institute of Malaya. 1960; 16:126-31.

[6] Brady, N. C.; WEIL, R. R. Elements of nature and soil properties. 3 ed., Bookman, Porto Alegre, 2013, 685 p.

[7] Christine l., R., The rehabilitation of quarries and open-pit mines, Montpellier Cedex 5 France, 15 pages. 2002.

[8] Cook, B. G.; Pengelly, B. C.; Brown, S. D.; Donnelly, J. L.; Eagles, D. A.; Franco, M. A.; Hanson, J.; Mullen, B. F.; Partridge, I. J.; Peters, M.; Schultze-Kraft, R., 2005. Tropical forages.

[9] Didby, W., Environmental and Social Impact Assessment of the Morila Mining Project, South Africa, 128 pages. 1999.

[10] Dirven, J. P. G., and Ehrencron, V: K. R. Surinaomse landbouw 11, 39-45. 1960.

[11] Djébré, LSM, Agronomic valorization of lime incrustations from the treatment of drinking water. DEA thesis, Nangui Abrogoua University, Abidjan, 54p. 2008.

[12] Dupuy, B. et N'guessan K., Sylviculture of Acacia mangium in lower Côte d'Ivoire, Bois et Forêts des Tropiques, n'25: pp.24-32. 1990.

[13] Ganry F., Sanogo Z. J. L., Gigou J. et Olivier R., Intensification of the cotton-sorghum system in South Mali based on manure and optimal fertilisation management. In: Fallow land in tropical Africa: Roles, arrangements, alternatives. Proceedings of the international seminar, Dakar, 13-16 April 1999, (1), Paris, John Libbey, 804 p. 2000.

[14] Gnahoua, G. M., Study of the weed flora of crops after improved fallow in the region of Oumé (Côte d'Ivoire). In: La jachère et maintien de la fertilité, Proceedings of the international workshop, Bamako, 2-4 October 1997, Dakar, Coraf/IRD/European Union, Paris, France, 146p. 1997.

[15] GREP, << Exploitation of the gold of Kédougou : no to the ecological disaster >>, Les GREP notebook, Sénégal N5, May 2012, 30p. 2012.

[16] Grof, D. Etablishment of legumes in humid tropic of northeastern Australia. Proc. XI Int., Agrost. Tech. Ann. Respt. $1966 ; 1 ; 14-15$. 
[17] Halim, R.A. Pueraria phaseoloides (Roxb.) Benth. In: 't Mannetje, L. and Jones, R.M. (eds) Plant Resources of SouthEast Asia No. 4. Forages. pp. 1997;192-194.

[18] Jacques E., Greffié C., Billa M., Thomassin J.F. and Zida B., 2006. Artisanal and small scale mines in Burkina Faso: today and tomorrow. Working paper of BRMG.

[19] Maradan D., Ouedraogo B., Thiombiano N., Thiombiano T., Zeik., Economic analysis of the mining sector links poverty and environment. sba-Ecosys-CEDRES. Report MECV Burkina Faso - May 2011, 69p.

[20] Melendez J., Becker M. and Johnson D., Mantaining the yield of uplandrice Mémoire de DEA. Université de Cocody, Abidjan, Côte d'Ivoire 32p. 2003.

[21] Sequeira, Cleiton Henrique de. Availability of micronutrients in soils and their correlation with leaf contents in young stands of eucalyptus. $45 \mathrm{f}$. Dissertation (Masters in Soil and Plant Nutrition) -Postgraduate Course in Soil and Plant Nutrition, Federal University of Viçosa, Viçosa, 2007.

[22] Tié, (B.T.), basis for fertilizing reasoning on the Agrilanddomain; mult. Report. 2005.

[23] Acevedo- Rodríguez, P. Los Bejucos de Puerto Rico. U.S.D.A. General Technical Report SO58, 1985.

[24] Akanza P. K. et Yoro G., Synergistic effects of mineral fertilizers and poultry manure in improving the fertility of a ferrallitic soil in western Côte d'Ivoire. African Agronomy 2003; 15 (3): 135-144.

[25] Golder, Associates, “Draft Report On Pit Slope Design Recommendations, Agbaou Project, Ivory Coast” 2008.

[26] Anderson JM, and Ingram JSI, Tropical soil biology and fertility. A handbook of methods. 2nd Ed. Wallingford-CAB International, 1993; 221p.

[27] Autfray P. et Gbakathectche H., Sowing of food crops in plant cover in forested areas of Côte d'Ivoire. In: "Agrobiological management of soils and cropping systems". International Workshop in Madagascar from 1999; 23 to 28.

[28] FAO, Grassland Index. A searchable catalogue of grass and forage légumes. FA0, Rome, Italy. 2015.

[29] Harmand,J. M. et Balle P. Agroforestry fallow (tree and shrub) in tropical Africa. In: Fallow land in tropical Africa: From natural fallow to improved fallow. Le point des connaissances, John Libbey, 2001; (2), Paris, France, 265292.

[30] Obatolu C. R. and Agboola A. A., The potential of Siam weed (Chromolaenaodorata) as a source of organicmatter for soils in humidtropics. In: Mulongoy K. and Merckx. P. (Eds): Soilorganicmatterdynamics and sustainability of Tropical Agriculture: 1993; 89-99.

[31] Taylor H., appleton j.d., lister R., Smith B., Chitamweba D., Mkumbo O., Machiwa J.F., Tesha A.L Beinhoff C., Environmental assessment of mercury contamination from the Rwamagasa artisanal gold mining centre, Geita District, Tanzania. Science of the Total Environment 2004; 3432005 111-133.

[32] Tian G., Mukhopadhyay P., Kirchhof G., and Carsky R. J., Effects of proceedings leguminous cover crop on soil N availability. Iinternational Symposium: The science and practice of short-term improved fallow. 11-15 Mars 1997; Lilongwe, Malawi: 48-70.

[33] Tian G., Stefan H., Koutika L.-S., Fusako I., and Chianu N., Pueraria cover crop Fallow systems: benefits and applicability. In: Warren A., Jerry L. and David M., Eds. Sustaining soil fertility in West Africa. 5-9 november 2000. Minnesota (USA): The Soil Science Society of America and the American Society of Agronomy Minneapolis, pp. $2001 ; 137-155$.

[34] Hardarson G, Danso SK. Methods for measuring biological nitrogen fixation in grain legumes. Plant and soil. 1993 Mar 1; 152(1):19-23.

[35] Duval L., - Cerulomobybdic dosage of phosphoric acid in soils, plants and fertilizers. Ann. Agron. 1962; 5: 469482.

[36] Parkinson RJ, Fuller MP, Groenhof AC. An evaluation of greenwaste compost for the production of forage maize (Zea mays L.). Compost Science \& Utilization. 1999 Jan 1; 7(1):72-80.

[37] Mbonigaba M.J.J. Study of the impact of plant biomass composts on the dynamics of physico-chemical, chemical and microbiological indicators of soil fertility: application on three acidic tropical soils in Rwanda. PhD thesis, FUSAGx, Gembloux, p 243. 2007. 
[38] Mze, S.P. Influence d'apports en matières organiques sur l'activité biologique et la disponibilité du phosphore dans deux sols de la région des grands lacs d'Afrique. Thèse de doctorat, Faculté Universitaire des Sciences Agronomiques de Gembloux, Gembloux, 240 p. 2008.

[39] Bertrand, R., Gigou, J. The fertility of tropical soils. Edt Maison neuve et Larose, Paris, France, p2000; 397.

[40] Andriamasinoro F., ANGEL J.M., Artisanal and small-scale gold mining in Burkina Faso: suggestion of multi-agent methodology as a complementary support in elaborating a policy. http://dx.doi.org/10.1016/j.resourpol.2012; $\underline{04.004}$.

[41] Ouédraogo A. H., mpact of artisanal gold mining (gold panning) on health and the environment. Management of Toxic Substances, West Africa Portal, http://www.mediaterre.org/afrique-ouest/actu,2006;1121095625.html. 